Scientific thinking in elementary school: Children's social cognition and their epistemological understanding promote experimentation skills

\title{
Scientific thinking in elementary school: Children's social cognition and their epistemological understanding promote experimentation skills
}

\author{
ONLINE SUPPLEMENT
}

\author{
Christopher Osterhaus \\ Dept. of Psychology \\ Freiburg University of Education
}

Susanne Koerber
Dept. of Psychology
Freiburg University of Education

and

Beate Sodian

Dept. of Psychology

University of Munich

The items presented in this online supplement are translated from German and reprinted from:

Osterhaus, C., Koerber, S., \& Sodian, B. (2015). Children's understanding of experimental contrast and experimental control: an inventory for primary school. Frontline Learning Research, 3(4), 56-94. doi:10.14786/fIr.v3i4.220

\section{Corresponding author:}

Christopher Osterhaus

Wisconsin Center for Education Research 1025 West Johnson Street

Madison, Wisconsin 53706

costerhaus@wisc.edu

+1 (608) 265-4579 
The scientist ...

\section{Task 1: Trees $(\mathrm{U} 1)$}

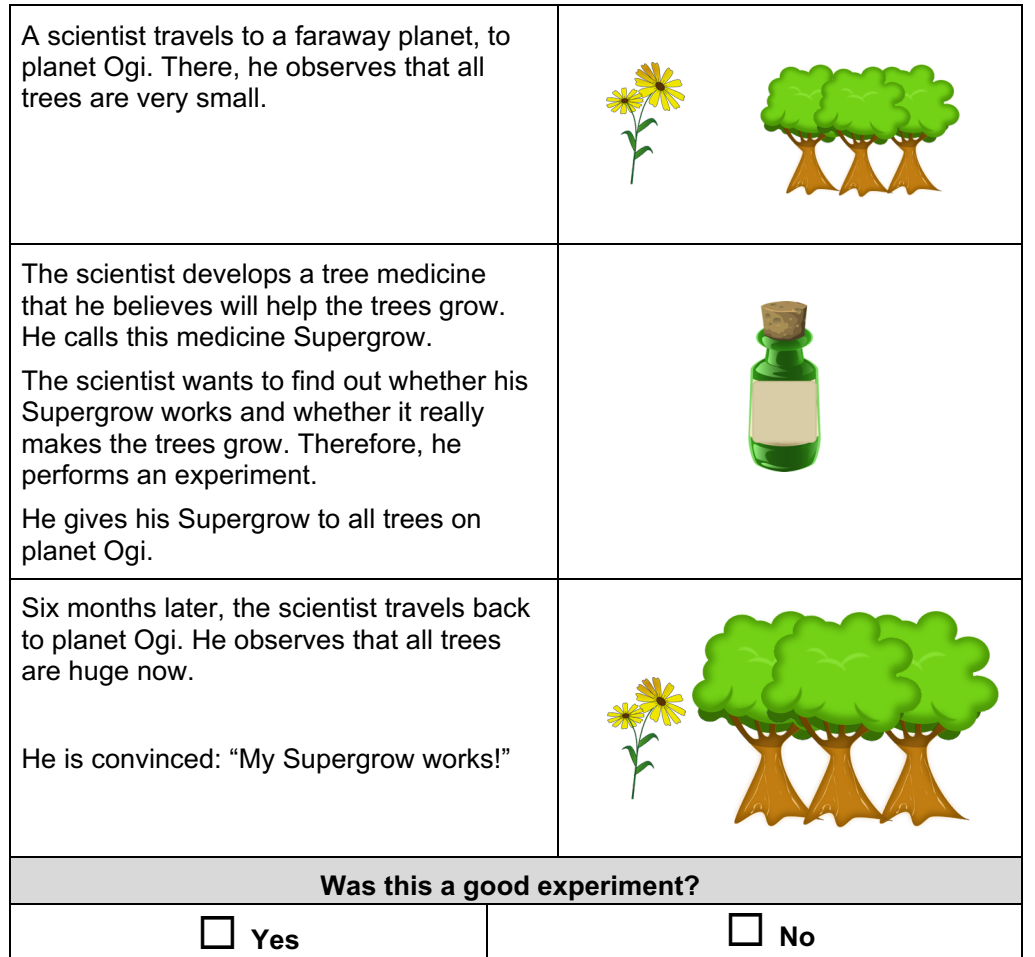

... and the trees

\begin{tabular}{|c|c|c|}
\hline $\begin{array}{c}\text { Sarah, Lisa, and Vera are talking about whether } \\
\text { experiment. }\end{array}$ & not this & as a good \\
\hline \multicolumn{3}{|l|}{ Who is right and who is not? } \\
\hline & is right & is not right \\
\hline $\begin{array}{l}\text { 1. Sarah says: "It was not a good experiment } \\
\text { because the scientist does not know how } \\
\text { big the trees would have grown without the } \\
\text { Supergrow." }\end{array}$ & $\square$ & $\square$ \\
\hline $\begin{array}{l}\text { 2. Lisa says: "It was a good experiment } \\
\text { because the scientist found that all trees } \\
\text { have grown huge after receiving the } \\
\text { Supergrow." }\end{array}$ & [ & \\
\hline $\begin{array}{l}\text { 3. Vera says: "It was a good experiment } \\
\text { because you can only see whether things } \\
\text { work if you test them." }\end{array}$ & $\square$ & $\square$ \\
\hline Which of the three girls has the best answer? & \multicolumn{2}{|c|}{ No. } \\
\hline
\end{tabular}


The math teacher...

Task 2: math textbook (U2)

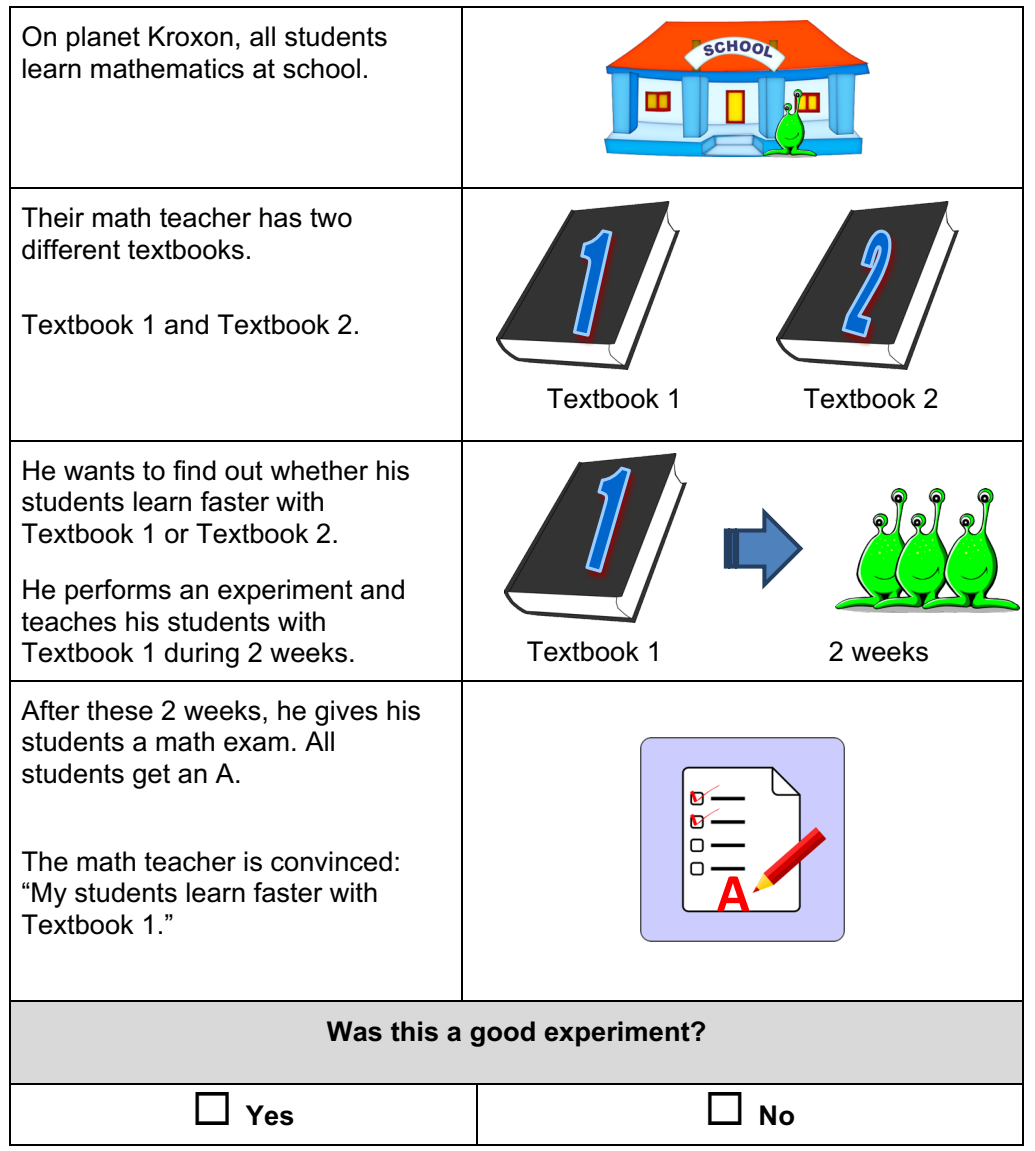

... and his students

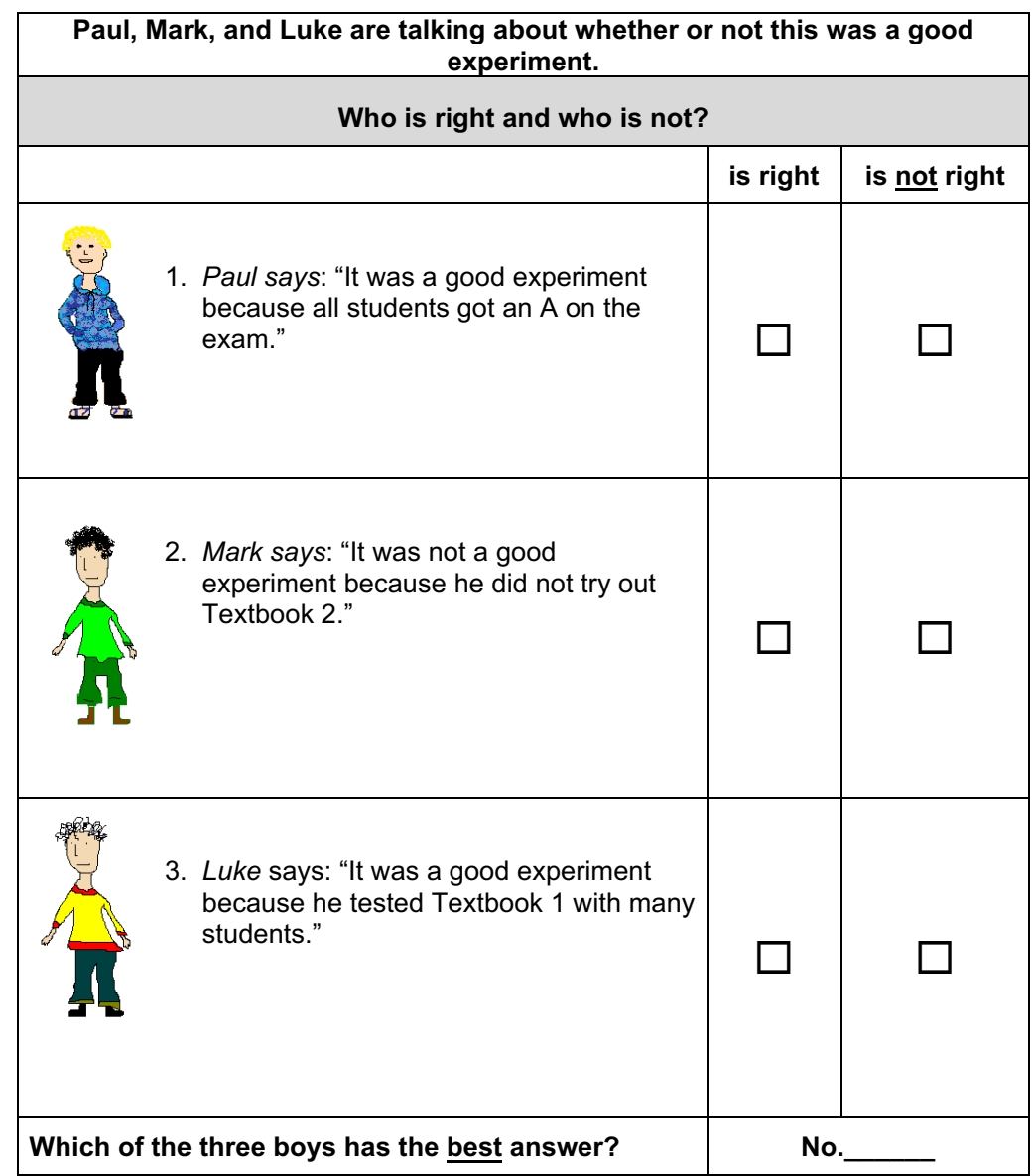


The headmaster ...

\section{Task 3: Classroom (U3)}

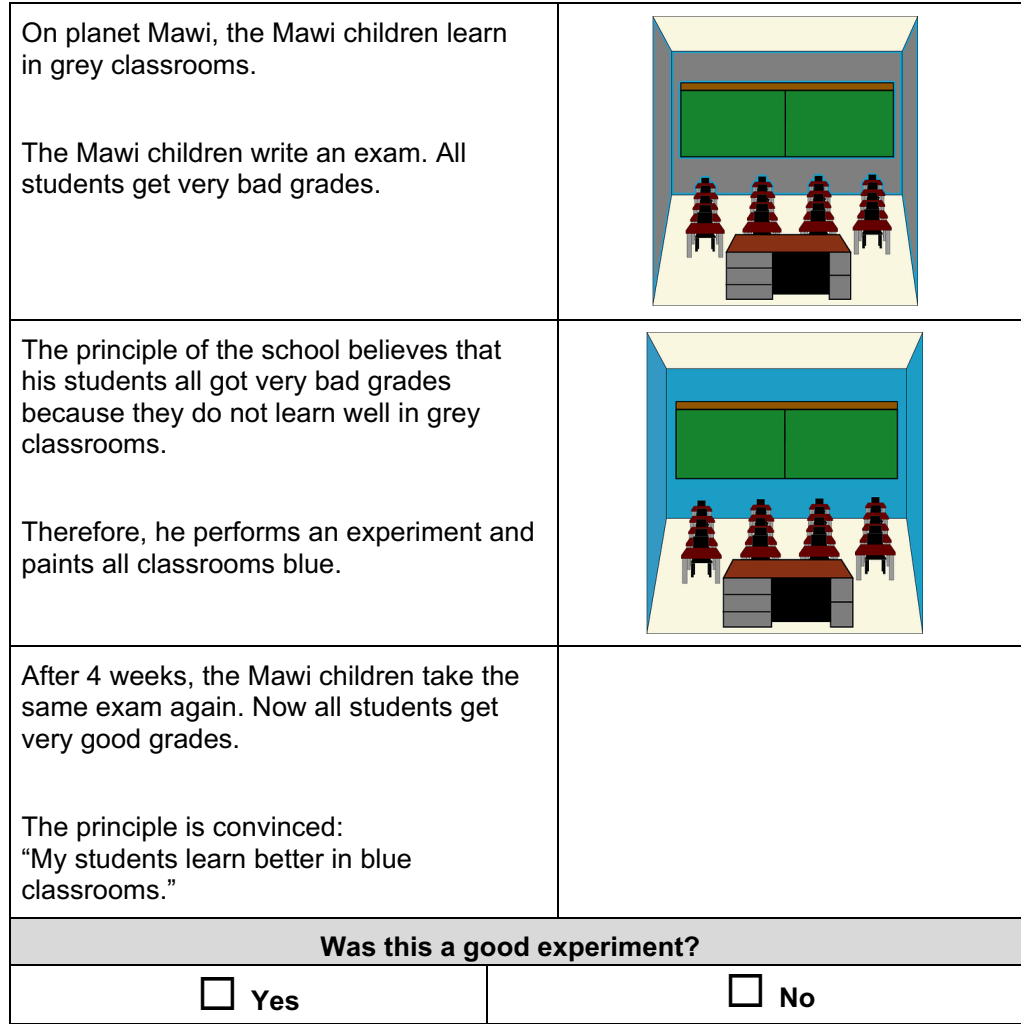

... and the classroom

\begin{tabular}{|l|l|l|}
\hline \multicolumn{3}{|c|}{ Sarah, Lisa, and Vera are talking about whether or not this was a good } \\
experiment.
\end{tabular}


The scientist ...

\section{Task 4: Light bulb (U4)}

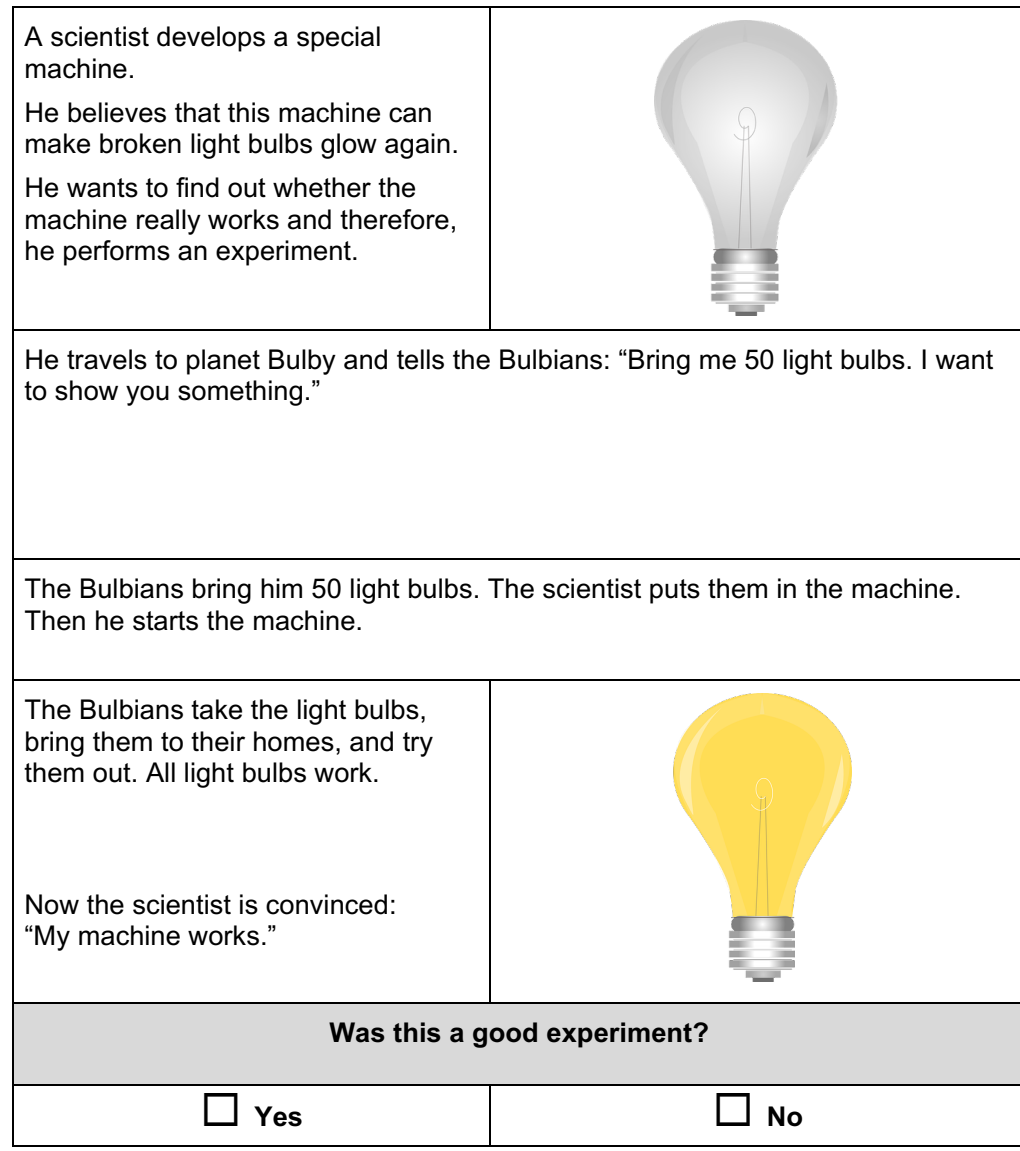

... and the machine

\begin{tabular}{|c|c|c|}
\hline $\begin{array}{c}\text { Sarah, Lisa, and Vera are talking about whether } \\
\text { experiment. }\end{array}$ & not this & as a good \\
\hline \multicolumn{3}{|l|}{ Who is right and who is not? } \\
\hline & is right & is not right \\
\hline $\begin{array}{l}\text { 1. Sarah says: "It was a good experiment } \\
\text { because all light bulbs work again after they } \\
\text { have been in the machine." }\end{array}$ & & \\
\hline $\begin{array}{l}\text { 2. Lisa says: "It was a good experiment } \\
\text { because he put many light bulbs in the } \\
\text { machine." }\end{array}$ & & [ \\
\hline $\begin{array}{l}\text { 3. Vera says: "It was not a good experiment } \\
\text { because he does not know whether or not } \\
\text { the light bulbs worked before he put them in } \\
\text { the machine." }\end{array}$ & & [ \\
\hline Which of the three girls has the best answer? & \multicolumn{2}{|c|}{ No. } \\
\hline
\end{tabular}


The scientist ...

\section{Task 5: Krogi (U5)}

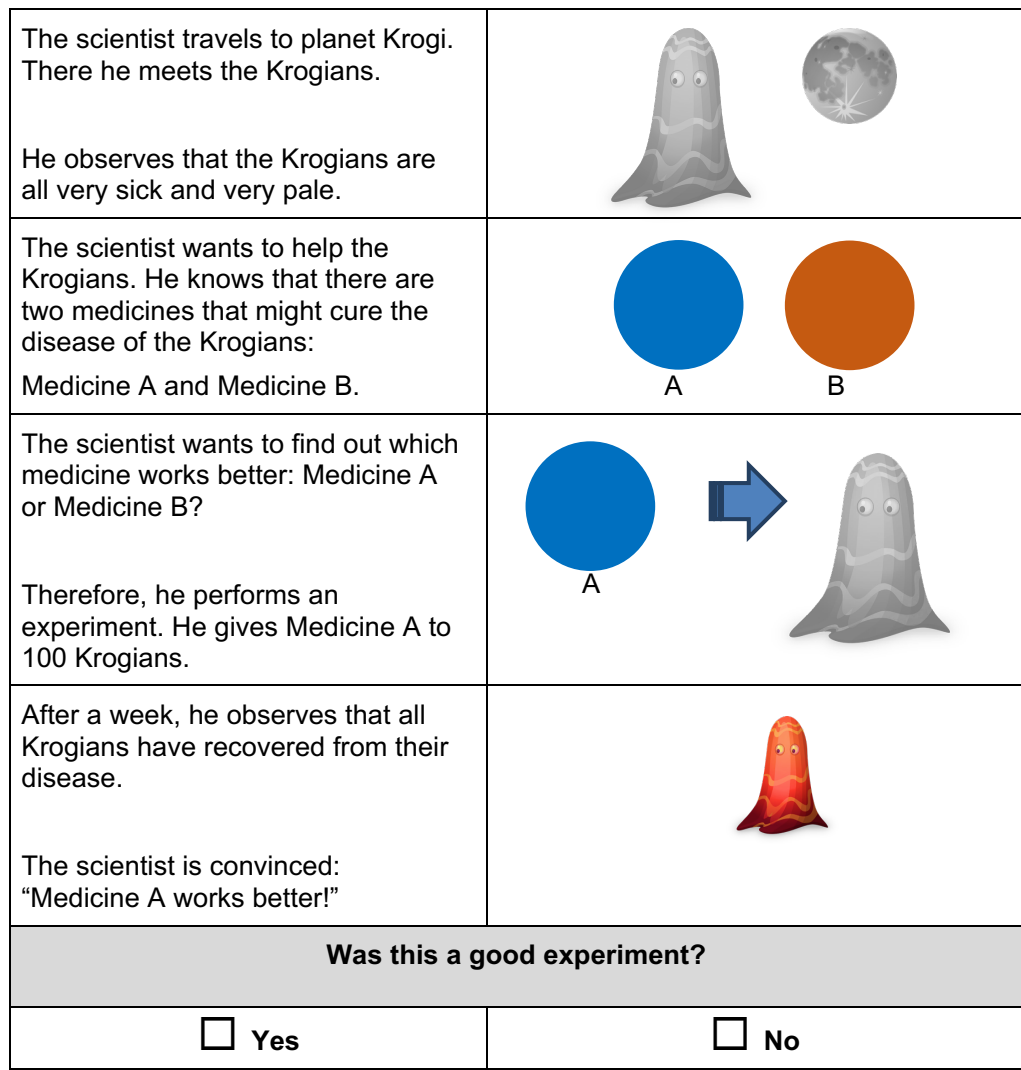

... and the Krogians

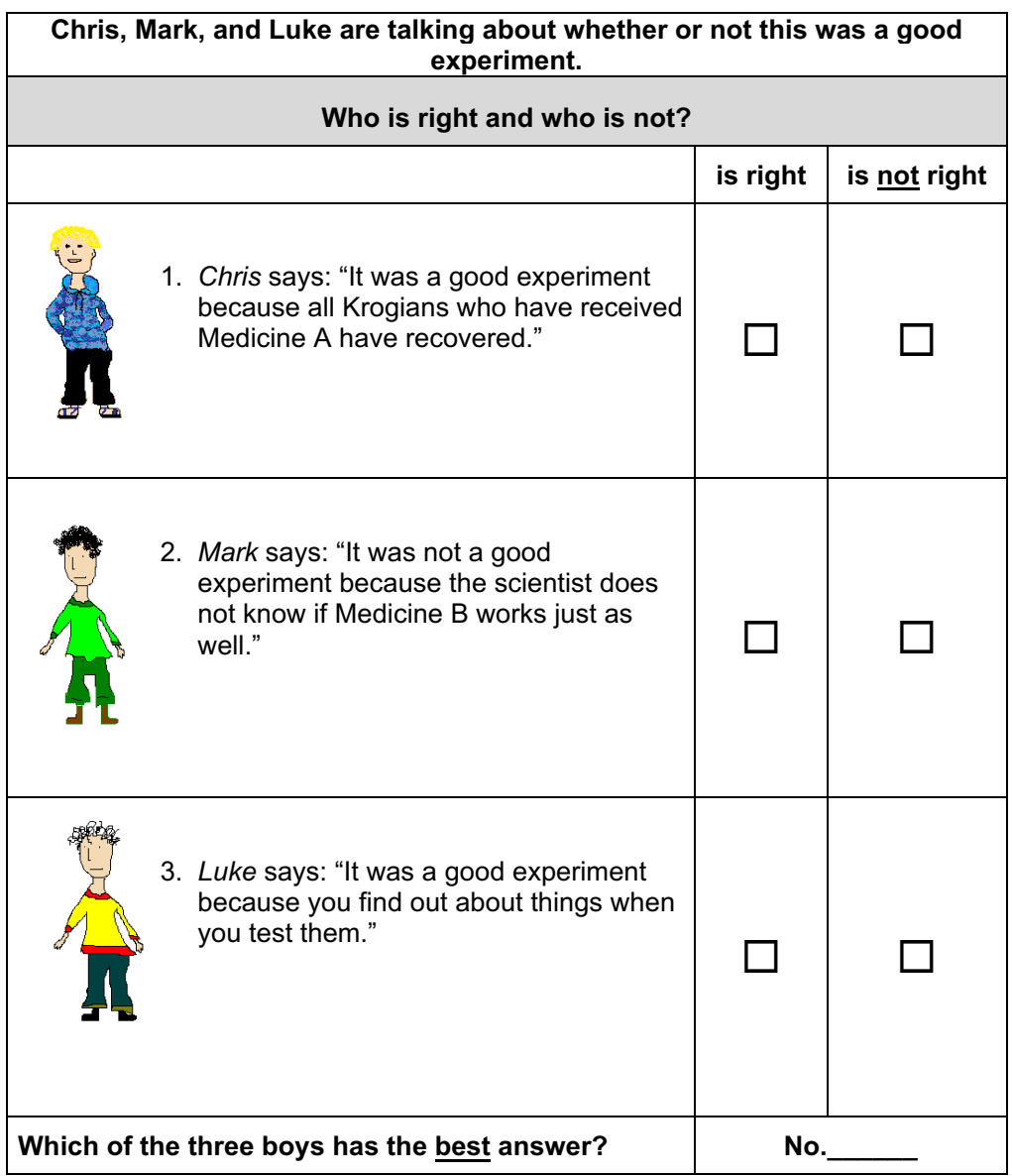


The hair dresser ...

\section{Task 6: Hair dresser (U6)}

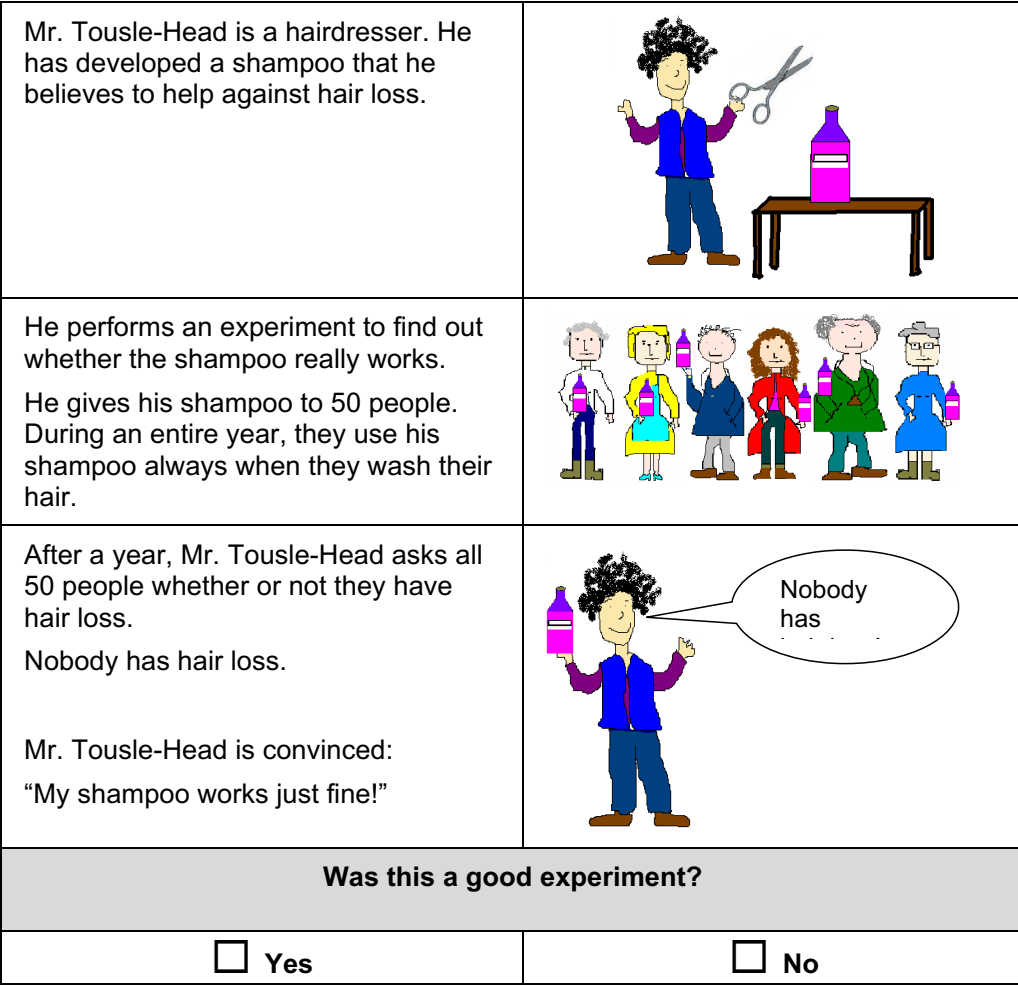

... and his shampoo

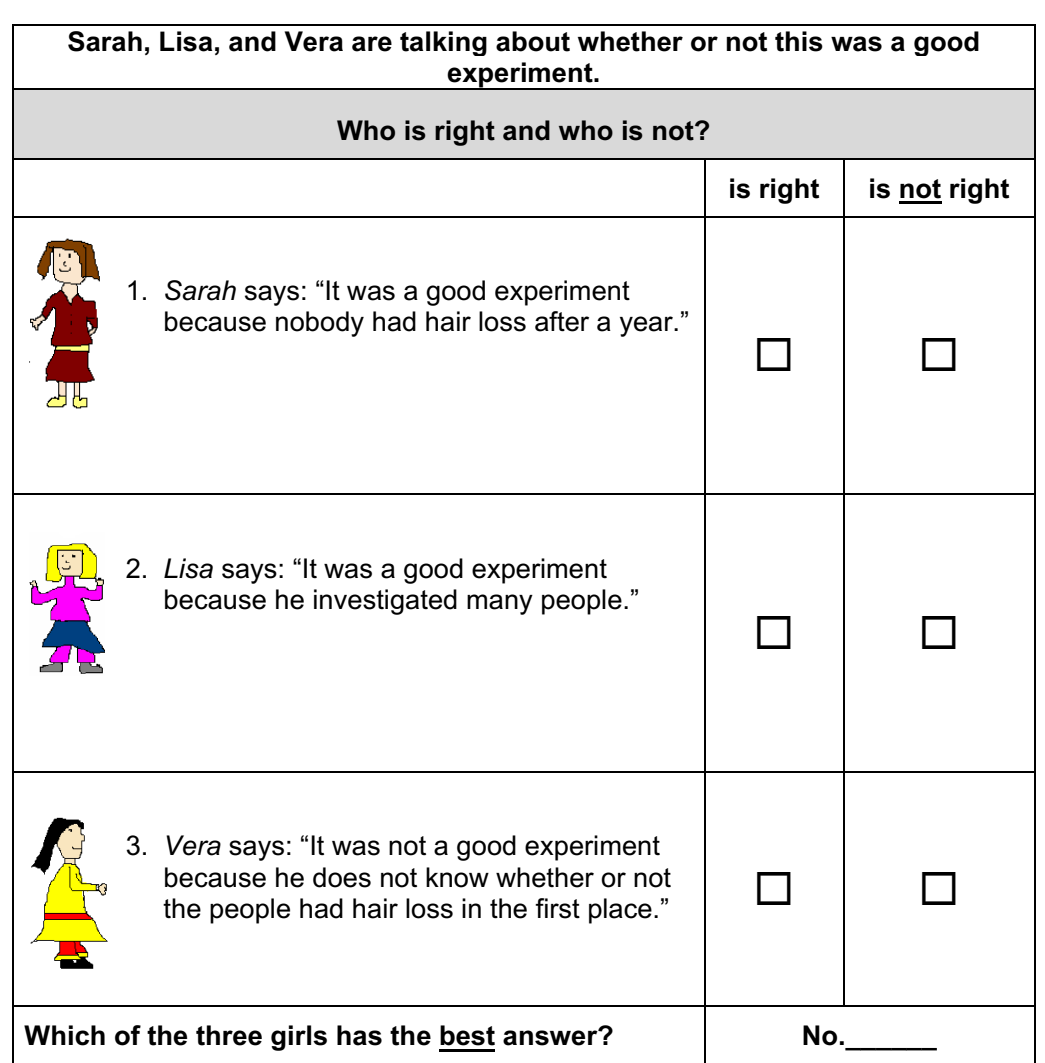




\section{The grannies.}

\section{Task 7: Grannies (U7)}

\begin{tabular}{l} 
Granny Bubu and Granny Kiki live on planet \\
lber. \\
Both grannies love flowers. \\
They want to find out what makes their \\
flowers bloom beautifully. Therefore, they \\
perform an experiment. \\
Granny Bubu waters her flowers with lake \\
water. \\
Granny Bubu's flowers bloom beautifully. \\
Granny Kiki waters her flowers with river \\
water. \\
Granny Kiki's flowers are withered. \\
Granny Bubu is convinced \\
"It's the lake water that makes my flowers bloom so beautifully." \\
\hline Yes this a good experiment?
\end{tabular}

$\ldots$ and their flowers

Nick, Thomas, and Simon are talking about whether or not Granny Bubu and Granny Kiki made a good experiment.

\begin{tabular}{|c|c|c|}
\hline \multicolumn{3}{|l|}{ Who is right and who is not? } \\
\hline & is right & $\begin{array}{l}\text { is not } \\
\text { right }\end{array}$ \\
\hline $\begin{array}{l}\text { 1. Nick says: "It was a good experiment } \\
\text { because all flowers that have been watered } \\
\text { with lake water bloom beautifully." }\end{array}$ & $\square$ & $\square$ \\
\hline $\begin{array}{l}\text { 2. Thomas says: "It was not a good experiment } \\
\text { because the grannies do not know whether } \\
\text { they do anything else differently, apart from } \\
\text { the water they use." }\end{array}$ & & $\square$ \\
\hline $\begin{array}{l}\text { 3. Simon says: "It was a good experiment } \\
\text { because you can only find out how good } \\
\text { something works if you try it out." }\end{array}$ & $\square$ & $\square$ \\
\hline Which of the three boys has the best answer? & No. & \\
\hline
\end{tabular}


The hospital ...

\section{Task 8: The Molans (U8)}

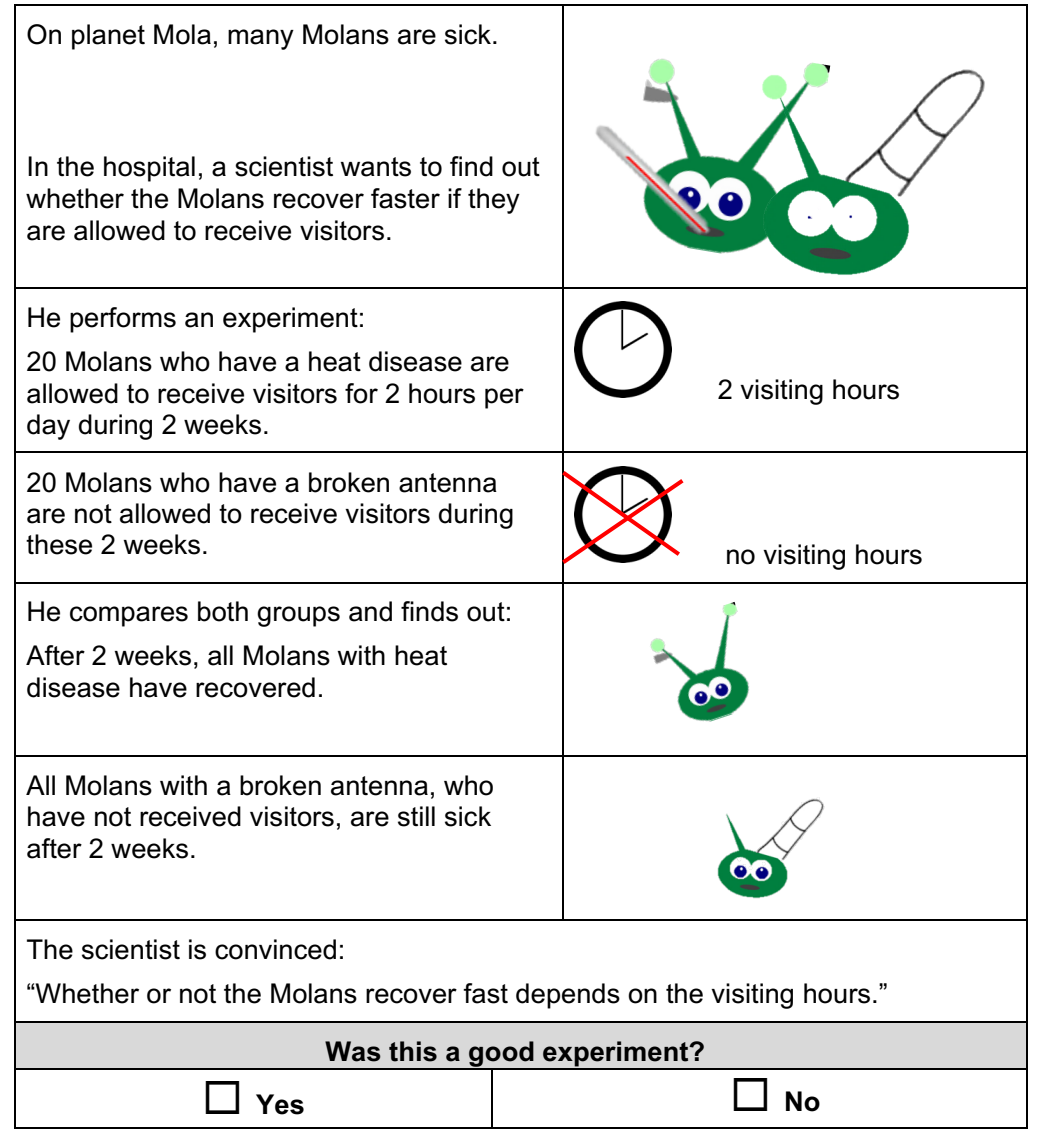

... on planet "Mola"

\begin{tabular}{|c|c|c|}
\hline \multicolumn{3}{|c|}{$\begin{array}{c}\text { Sarah, Lisa, and Vera are talking about whether or not this was a good } \\
\text { experiment. }\end{array}$} \\
\hline \multicolumn{3}{|l|}{ Who is right and who is not? } \\
\hline & is right & is not right \\
\hline $\begin{array}{l}\text { 1. Sarah says: "It was not a good experiment } \\
\text { because the scientist should have compared } \\
2 \text { groups of Molans with the same disease." }\end{array}$ & $\square$ & $\square$ \\
\hline $\begin{array}{l}\text { 2. Lisa says: "It was a good experiment } \\
\text { because he investigated many Molans." }\end{array}$ & & \\
\hline $\begin{array}{l}\text { 3. Vera says: "It was a good experiment } \\
\text { because } 20 \text { Molans have recovered from } \\
\text { their disease." }\end{array}$ & $\square$ & \\
\hline Which of the three girls has the best answer? & No & \\
\hline
\end{tabular}




\section{Ms Mef ...}

\section{Task 9: Ms Mef (U9)}

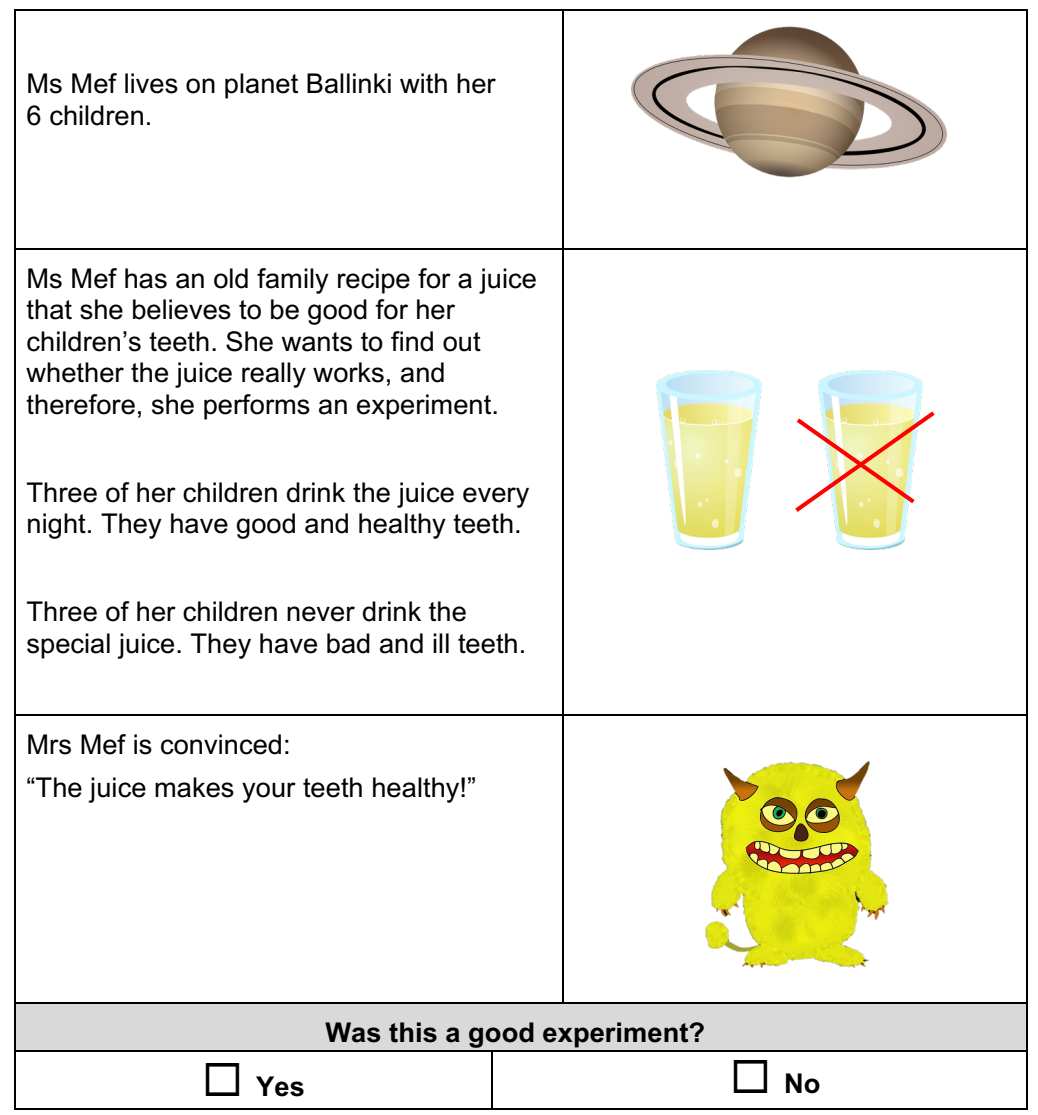

... and her family recipe

\begin{tabular}{|l|l|l|}
\hline \multicolumn{3}{|c|}{ Sarah, Lisa, and Vera are talking about whether or this was a good } \\
experiment. \\
\hline \multicolumn{3}{|c|}{ Who is right and who is not? } \\
\hline $\begin{array}{l}\text { 1. Sarah says: "It was a good experiment } \\
\text { because all children who drank the juice } \\
\text { have good teeth." }\end{array}$
\end{tabular}


The principle...

Task 10: The principle (U10)

\begin{tabular}{l} 
On planet lber, all Iber children have to go to school. \\
However, they all get very bad grades. The principle \\
of their school has three different ideas about why his \\
students get such bad grades: \\
1. Iber teachers have too high standards. \\
2. Iber children do not work hard enough. \\
3. The lber school is too small and the children \\
cannot concentrate in the small rooms. \\
The principle makes a scientific \\
study. He takes a look on the \\
neighboring planet where children get \\
very good grades. \\
He finds that indeed classrooms on \\
the neighboring planed are much \\
bigger. \\
\hline The principle is convinced: \\
"The Iber children get bad grades \\
because the classrooms on planet \\
Iber are too small."
\end{tabular}

... and his school

\begin{tabular}{|l|l|l|}
\hline \multicolumn{2}{|c|}{ Wick, Thomas, and Simon are talking about whether or not this was a } \\
good experiment.
\end{tabular}


The flowers ...

Task 11: Flowers (U11)

\begin{tabular}{l} 
All flowers on planet Blossom are sick and withering. \\
A scientist thinks that there may be three reasons for \\
why the plants are getting sick: \\
1. They do not get sufficient sunlight. \\
2. There is too much wind. \\
3. The soil is not fertile. \\
The scientist performs an experiment. He \\
takes 50 flowers and takes them to a \\
different spot where they receive much \\
more sunlight. \\
Indeed, the flowers are not getting sick in \\
their new location. \\
The scientist is convinced: \\
"The reason for why the flowers got sick \\
is that they did not get sufficient \\
sunlight." \\
$\qquad$ Yes \\
\hline
\end{tabular}

... on planet Blossom

Nick, Thomas, and Simon are talking about whether or not this was a good experiment.

\begin{tabular}{|c|c|c|}
\hline \multicolumn{3}{|l|}{ Who is right and who is not? } \\
\hline & is right & is not right \\
\hline $\begin{array}{l}\text { 1. Nick says: "It was a good experiment } \\
\text { because he took many plants to a different } \\
\text { spot and observed them." }\end{array}$ & $\square$ & $\square$ \\
\hline $\begin{array}{l}\text { 2. Thomas says: "It was not a good } \\
\text { experiment because he does not know } \\
\text { whether the wind or the type of soil would } \\
\text { have made a difference." }\end{array}$ & $\square$ & $\square$ \\
\hline $\begin{array}{l}\text { 3. Simon says: "It was a good experiment } \\
\text { because the flowers are not sick anymore." }\end{array}$ & $\square$ & $\square$ \\
\hline Which of the three boys has the best answer? & Nc & \\
\hline
\end{tabular}

